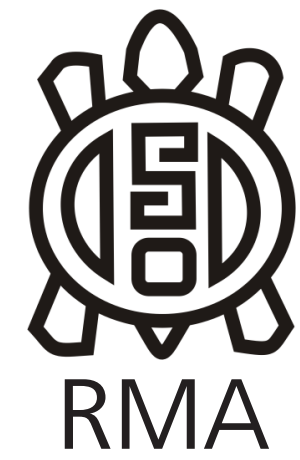

Dossier

\title{
Where does language come from?
}

\author{
¿De dónde viene el lenguaje?
}

Ruth Finnegan

Emeritus Professor, Sociology, Faculty of Social Sciences, The Open University, United Kingdom. Email: r.h.finnegan@open.ac.uk

\begin{abstract}
It is always interesting to ask about the origin of things, but for this we also need to consider what it is for which we seek the beginning. What, then, is 'language' - voice, words, text? This leads to a number of questions: what are the current and earlier theories about how language began? did language come just once to humankind and from one single source? can language and verbal text come in dreams and visions (the paper discusses and analyses an ethnographically-attested example of this)? what of the source of the multiple languages we know today? how and in what form(s) do we create language anew? Much of the earlier theorising centred on speech - that is, on oral (in practice multi-sensory) language. But there are also the written forms of language. The emergence and the number of scripts is remarkable, as are, when we know them, their creators. How did these many forms of written language start? Language is a key human-divine art, among our greatest, to be celebrated. Yet in a sense we know so little about it and are right to continue our search for its origin.
\end{abstract}

Keywords : language; anthropology; orality; writing; dream

\section{Resumen}

Siempre es interesante preguntar sobre el origen de las cosas, pero para esto también debemos considerar qué es para lo que buscamos el principio. Entonces, ¿qué es 'lenguaje' - voz, palabras, texto? Esto lleva a una serie de preguntas: ¿cuáles son las teorías actuales y anteriores sobre cómo comenzó el lenguaje? ¿el lenguaje vino una sola vez a la humanidad y de una sola fuente? ¿puede el lenguaje y el texto verbal aparecer en sueños y visiones (el documento discute y analiza un ejemplo atestiguado etnográficamente de esto)? ¿Qué hay de la fuente de los múltiples idiomas que conocemos hoy? ¿cómo y en qué forma (s) creamos el lenguaje de nuevo? Gran parte de la teorización anterior se centró en el habla, es decir, en el lenguaje oral (en la práctica multisensorial). Pero también están las formas escritas del lenguaje. La aparición y el número de scripts es notable, como lo son, cuando los conocemos, sus creadores. ¿Cómo comenzaron estas muchas formas de lenguaje escrito? El lenguaje es un arte humano-divino clave, entre nuestros mejores, para ser celebrado. Sin embargo, en cierto sentido, sabemos muy poco al respecto y estamos en lo cierto al continuar nuestra búsqueda de su origen.

Palabras clave: lenguaje; antropología; oralidad; escritura; sueño

We humans have resources, handed down from our ancestors, for the generating and utterance of beautiful poetic and loving words. As the ancients saw well, here is a divine gift, from the past, from the creation of the seers and poets of old. But from where can this wondrous resource have come in the first place? Whence the origin of the miracle of language?

The question still attracts immense interest and in some ways a vast literature surrounds it with a constant stream of compilations and commentaries. A plethora of literary, historical and anthropological studies have examined aspects of the use or collection of language in particular places or periods - and, especially, of quoted language from the generated heritage of the past - linguists and philosophers have engaged in technical analyses, literary and cultural scholars developed a variety of approaches to allusion, citation or creativity and the topics of intertextuality, originality and appropriation become a focus of interest to, among others, cultural historians, educationalists and postmodernist scholars, But amidst this profusion there seems little direct treatment of the question teasing me: about how such a wondrous human gift could have arisen in the first place. A question indeed.

It is not an unreasonable one either. To tell the truth we are all fascinated by origins. Indeed sometimes it seems a presupposition that it is only by finding where and how 
and perhaps by whom something first began tat we can fully understand and define its nature.

That doesn't really follow. But there is something in this approach, once much loved by anthropologists and others, and I shall in broad terms be following it here. It can throw a fuller light on the nature and use of language.

So, before getting into specific examples or, anthropologywise, the ethnography let us consider what theories, convincing or otherwise (and some are fantastically speculative) have been offered about this? Much of this is just to repeat what is well-known but, as, hopefully, will emerge, some survey of their import can be helpful.

Theories about the origin, or at any rate, the nature of language go back, typically, to the Greeks, maybe earlier. The Greek historian Herodotus in Book 2 chapter 2 of his histories reports an Egyptian experiment, conducted by the then Pharoah Psammetichus to test the then widespread assumption that the Egyptians were the oldest people on earth (language, interestingly, being regarded as the key for deciding this):

He took two newborn children of the common people and gave them to a shepherd to bring up among his flocks. He gave instructions that no one was to speak a word in their hearing; they were to stay by themselves in a lonely hut, and in due time the shepherd was to bring goats and give the children their milk and do everything else necessary. Psammetichus did this, and gave these instructions, because he wanted to hear what speech would first come from the children, when they were past the age of indistinct babbling. And he had his wish; for one day, when the shepherd had done as he was told for two years, both children ran to him stretching out their hands and calling «Bekos!» as he opened the door and entered.

His conclusion was that, since 'bekos' was the Phrygian word for bread the Phrygians were after all the oldest people. Not so stupid - and we will be coming back to this question of who 'the oldest' or 'the first' people' were and the relevance of this for the origin of language.

Then there was the biblical theory - myth some might call it - of the Tower of Babel, an important tale that, again, I must come back to.

There have been multiple theories since. I specially like the way that Max Müller (1861) jokingly but in fact rather accurately, summed these up as The 'bow-wow' or 'cuckoo theory': the German philosopher Johann Gottfried Herder saw the beginning of language as coming from humans' attempts to imitate animal and bird cries. There is certainly something in this, for (as elaborated in Finnegan 2013) there is much greater continuity between animal and human communication than often realised. But as a general theory of the origin of language it seems too limited to be convincing.
The 'pooh-pooh theory' (or, more grandly the 'interjectional' theory) is a constantly and still - influential approach. It too goes back to the Greeks. In the fifth-century BC the philosopher-scientist Democritus and his followers argued that human speech derived from sounds and cries of an emotional nature, either their own or as imitated from animals. This latter approach was poetically expressed in Lucretius; great De Rerum Natura, a thoughtful account still worth quoting at some length:

\section{To think}

That in those days some man apportioned round To things their names, and that from him men learned Their first nomenclature, is foolery.

For why could he mark everything by words

And utter the various sounds of tongue, what time

The rest may be supposed powerless

To do the same? And, if the rest had not

Already one with other used words,

Whence was implanted in the teacher, then,

Fore-knowledge of their use, and whence was given

To him alone primordial faculty

To know and see in mind what 'twas he willed?

Besides, one only man could scarce subdue

An overmastered multitude to choose

To get by heart his names of things. A task

Not easy 'tis in any wise to teach

And to persuade the deaf concerning what

'Tis needful for to do. For ne'er would they

Allow, nor ne'er in anywise endure

Perpetual vain dingdong in their ears

of spoken sounds unheard before. And what,

At last, in this affair so wondrous is,

That human race (in whom a voice and tongue

Were now in vigour) should by divers words

Denote its objects, as each divers sense

Might prompt?- since even the speechless herds, aye, since

The very generations of wild beasts

Are wont dissimilar and divers sounds

To rouse from in them, when there's fear or pain, And when they burst with joys. And this, forsooth, 'Tis thine to know from plainest facts: when first Huge flabby jowls of mad Molossian hounds, Baring their hard white teeth, begin to snarl, They threaten, with infuriate lips peeled back, In sounds far other than with which they bark And fill with voices all the regions round ...

(Lucretius De rerum naturae, Book 5 lines 1026ff, translated William Ellery Leonard)

The same idea was later taken up by the influential European seventeenth- to eighteenth-century thinkers Vico and Rousseau. According to them language had its origin in emotional reactions - a gasp, gulp, sob, shriek, laugh sometimes then with a deliberate vocalized concomitant as interjectionstriggered by surprise, pain, pleasure, and so on - 'ohh!', 'ouch!', 'agh!' - further elaborated as, and something we still find in, exclamations like 'wow' 
, 'phew!', or 'oh dear', which in a way are semantically meaningless yet somehow convey intense meaning. We can see how on this theory this could eventuate in such sentences as 'I'm so sorry', 'ooh that is so painful', 'how wonderful' and so on with more complex forms of language gradually evolving up from that.

In the nicely-named 'ding-dong theory' all things have a vibrating natural resonance, echoed somehow by man in his earliest words. This in a way fits with recent innovative scientific views that all things are in a way conscious and thus somehow naturally in communication (more on this later). It is also consonant with the view that music in some way lies at the root of human language and communication.

Sometimes several approaches are combined. As Darwin had it

I cannot doubt that language owes its origin to the imitation and modification, aided by signs and gestures, of various natural sounds, the voices of other animals, and man's own instinctive cries (Darwin 1872: 56).

This was not the end of it however. Müller continues with the:

The 'yo-he-ho theory'. This envisaged language as emerging from collective rhythmic labor, the attempt to synchronize muscular effort" think 'yo-oh heave ho' or 'row row row the boat ...' . This usefully reminds us of work songs, ubiquitous, it seems, throughout the world. These, again synchronising sound and movement, have been seen, as for instance in the seminal work by Jousse (1925), as the primordial origin of language, and again bringing out the role of music in speech, and hence in language.

Then, noted a bit later by Richard Paget (1930) - not in Müller's list - there was

The 'ta-ta theory': humans made the earliest words by mimicking manual gestures with their tongues, thus rendering them audible. Think for example of words like bumps a daisy, oh la la, tantara-taan-tara, amin/amen.

This theory is worth lingering over. It suggests that human language developed from the gestures that were once in primaeval times used for simple communication. These were jointly facilitated, it seems, by neural systems, close and parallel for both gesture and vocal language. The theory is further supported by the plentiful evidence for non-human primates using gestures for at least some form of communicating: indeed some animal gestures (for example the chimpanzee 'begging posture' with the hands stretched out) show a striking resemblance to those of humans. Gestures seem to be an intrinsic element of primate communication, supporting the theory that language gradually evolved from gesture. In addition gestures are important in human infancy and can also, as shown in signing systems for the deaf, be developed into full languages.
The important question for gestural theory or theories (a fairly broad church arena) is why and how there could have been a shift to vocalization. One possible scenario - a plausible hypothesis - is that as humans became bipedal they increasingly used their hands for other tasks, thus taking over from communicative gesture, and/or had the ease of locomotion needed to move further away from each other with a consequent need to communicate when out of sight; hence audition, through the voice, rather than through the sight of visible gesture became increasingly emphasised.

Not that the shift was total of course for gestures are still important in human communication, if often below the level of consciousness. It is not just our hand movements either, though these are traditionally the main focus, but also facial expression (which can be seen as a form of gesture) , posture, gait, indeed the movement of the body as a whole (well studied in recent years in such works as Kendon 2004, MacNeill 2005), Nowadays indeed many linguists see a continuity between gesture and verbal language or, even more strongly, see them as essentially dimensions of a single syndrome - 'language'.

The 'la-la theory' sees language as originating in playfulness and artistry - think of trills, verbal decorations and fill-ins: meaningless words ('words'), in on sense, like tra-la-la, fal la la la laa, fol-de-rol, hallelujah. It is an attractive theory for its persuasive link between language and art. This is the more important in that the emphasis in many recent approaches to language has been on the 'informationproviding', 'cognitive', 'prosaic', and/or 'message-sending' version of communicating, defining language (and, indeed, communicating) exclusively in those terms taking, therefore, little account of the artistic and multi-sensory elements which are in practice so important in our linguistic and other communicating.

There may seem little point in reviving these old and arguably long-outdated theories of language. In fact when the eminent 'Paris Linguistic Society' was founded in 1866 they thought these theories so useless that their by-laws actually prohibited any discussion of them! That didn't stop people asking! And their existence and longevity of such theories certainly show how long humans have puzzled over, and sought, answers to this long-asked question (longer too, no doubt, than we can now trace). Essentially too they are of interest as being less about the origin of language than, ultimately, about its nature. What could be a greater topic than this for us human beings?

I believe too that, though scarcely tenable in a literal sense, these diverse attempts to tackle the great question of the origin of our human language do indeed throw light on various, diverse, dimensions of that great human art, language, some of them notably neglected in the present emphasis on cognition and deliberation. Some of them, it is true, give us only a limited view of language and its uses. 
But at the same time, and taken together, they do without doubt help to bring out something of its complexity and the many purposes to which we humans can turn our gift of language. They also in some ways foreshadow some of the findings, or, at any rate questions, of modern linguistic theory.

What are the characteristics, then, of these earlier theories?

First, they all appear to focus primarily on words (what are 'words'? an elusive and limited concept indeed for suited to writing than speech, but, roughly, some isolatable and isolated linguistic bit or small verbal chunk). This seems only sensible. After all we all start from the idea of words when we read, and both the mono- and poly-glot language dictionaries, that near ubiquitous resource in literate contexts, are made up of words. It is what they do, and that seems sufficient to capture language for us. All done! The words in these books, and elsewhere, would seem to be unquestionable things, fully existent objects standing independently and objectively in the real world. They exist too, proven, as things that children and students and foreign language learners have to learn to spell. This has never been an incontrovertible matter (think of the changes in spelling over the last years, or the differences within and between different versions of English), and indeed something that was fully unsettled for some centuries after the early days of print - there is no intrinsic 'correct' way of spelling. But on the face of it that learned spelling would seem to attest the reality of the things, the words, that they make up and define - our language.

For all their fluidity and uncertainty, whether short or long, sounded or silent, fleeting, elusive, or permanent, the things that we class as 'words' have been the basis of great art forms, culturally formed, and, wherever they originally come from, themselves influential. Among other things they can have the magic power to unite a nation - as with the languages that uphold the image and the actuality of Finland, Britain, Portugal, Brazil. Or the foundation of great speeches, or prayers or of literary art like Shakespeare sonnets, the translation of Rumi's mediaeval mystic poems, of quotation, proverb, allusion. Why would we not accord them reality?

So - it is not irrelevant that the origin of words and their usages have played so large a part in theories of language origin. But could 'words' ever be a guide to the origin of 'language'? More to the point, is language made up just of words? Surely not. It is the relations between the words, their rubbing together, grammar, syntax, connotations, that between them make up language. It is the'between-ness' that matters. Language is a system not a conglomeration of separate items and could not possibly have been built up brick by separate brick For by all counts language is a whole, not a conglomeration of words or any other kinds of bits, or sounds, or gestures or mothers' crooning or vocal grooming, or whatever.
It is this holistic nature of language that is missed in the early theories of language origin - indeed in the connected, implied, theories of the nature of language itself. In that respect they are all equally inadequate.

So too are they in pointing, each, to only one or at most two dimensions of language. They are, certainly, good in reminding us of facets often forgotten in the present rush to cognitive studies. But in the end - and here most critics agree - language is more than just interjections, art, emotion, mimicry or the accompaniment to muscular motion. It is an all-purpose or near all-purpose human tool.

There is an interesting second point too. These theories, for all their diversity in other respects, agree in focusing our attention not on the cognitive or abstract side of language, but on its practice: its manifold and manifest uses in the world. In this - an important point - is consonant with one of the two great schools of language today, that of pragmatism (Ariel 2010, Duranti 1997, Verschueren et al. 1995). Far from turning us to focus on language as something inside the mind, as in Chomsky's rightly influential writings (2007 and elsewhere) it forces us to recognize its multiple culturally-designed usages as art, as communication, as expression, and as a resource open to being driven by emotion. In this, again, the ancient theories are much in accord with the insights of today.

A third point is that all these theories fall into the 'continuity' rather than 'discontinuity' category of origins, the two broad branches into which language theory is divided today. They envisage language as gradually developing, whether from animal mimicry, work songs, gestures or whatever until it finally arrived, somehow, at the full and supposedly perfect system we have today. There is no hint in these earlier theories of any possibility of a single sudden invention or discovery. One of the arguments used to support this view is that that language is characterized by so much complexity that it simply could not have arisen from nothing in its final form; therefore it must have evolved from earlier pre-linguistic systems among our primate ancestors.

But when I again wonder about the origin of language I am drawn to consider the (more recent and yet ancient) discontinuity theories. How could language have started off bit by bit when, as I have said, its very definition presupposes an integrated interrelated system? If it was not the result of blind evolutionary forces or deliberate creation or somehow emerged from the time when 'the ape came down from the trees and needed to communicate' (a pretty tale) - then how did such a holistic system come into being: a whole, again a system?

The question demands a wider perspective. The conventional ethnographic viewpoint privileges a short-scale, local, focus. So too, surprisingly, do studies of the Chinese or the ancient classical world where I tried to contextualise contemporary snapshots by a longer vision. For though there is now some general interest across the better informed social sciences 
in psychiatric perspectives and 'the imaginary' much is still aligned towards the hard sciences rather than the 'liquid' and dreamed knowing that demands exploration.

So it id perhaps not surprising that a majority of linguistic scholars currently hold continuity-based theories. They differ however in how they envision language developing. Some see language as essentially innate, others (like Steven Pinker) assume that the human development of language must have evolved in the usual gradual way. Others believe language came not from primate communication but - more complex - from primate cognition, which is significantly more complex. The problem with such theories is their narrowly mechanistic nature - as if our ancestors just stumbled upon some ingenious mechanism for linking sounds with meanings, and language then automatically evolved.

This turns many, like myself, once more to discontinuity theory - the once-and-for-all emergence of human language. For consider. It is now apparently agreed that homo sapiens emerged just the once, in Southern Africa - miracle enough. Then, it seems, they spread throughout the globe - and if 'sapiens', then surely with language: is that any the more miraculous to believe? After that continuity, normal everyday continuity, could come into play. Parents could teach verbal speaking day by day to their children and thus language was passed on over the centuries and millennia and perhaps more to reach us, in all its diversity this very day.

So think again of those first humans, few perhaps and struggling - but speaking. And whether we think of this as a kind of divine gift or, with Chomsky (perhaps the same thing ultimately) as a kind of genetically encoded innate faculty resulting from a single chance mutation occurring in one individual perhaps 100,000 years ago, instantaneously installing the language faculty (a component of the mindbrain) in 'perfect' or 'near-perfect' form (thus Noam Chomsky, a leading proponent of the discontinuity onceoff theory), speaking was there in these early humans. And not in one either, for speaking presupposes not just a speaker but also at least one listener and responder. Either way - there was language, full and whole. As Sapir (1921) so wisely pointed out many years ago there is no such thing as a 'primitive or 'undeveloped' language: language is language, or not at all. For that, it must indeed have appeared quite suddenly, ready and waiting, in the history of humankind: a once-and-for-all monogenesis.

How much we owe to that small human band, the first. How could language, like them, not have been formed just the once? And if, as now seems agreed, there was just this one original human group destined to spread in amazing ways across Africa, across Europe and, before the breakage of continents, into Australia and the Americas, carrying, as we anthropologists know so well, their cultural heritage with them - if so, how could language, that originary imaginative creation of speech, not have travelled with them?
Language then, originated but the once.

But no, exclaim some thinkers, it is being created every day. That indeed is another, equally valid and by no means contradictory, way of looking at it. Recent accounts (such as Carter 2004, Swann et al. 2011) have highlighted the creativity not just of 'art' events and inventions but of everyday language too and how it is spoken. There is no need to look to the far 'beginnings' of humankind for the origin of language, for every day, in literature, in oratory, in common speech, in converse with infants or with lovers, we see its beginning for ourselves, in our very time and place, the originating of language, an equal miracle.

And in gathered and publicised and visble chunks of words too. Where do they come from? Poets and speakers have pondered this point and found many ways to try to describe the process, unique perhaps to each individual. Certainly there are many diverse ways to linguistic-literary creation. In the spirit of ethnography let me take just one. It is a well-observed and documented example too, for it is from my own first-hand observation and experience.

One dawn a few years ago as the sun rose over the beautiful Hauraki Gulf and its surrounding mountains in Auckland, New Zealand, I found a poem in my mind. I had not planned or sought it (I did not write poetry) - but there it was. I did not search for rhymes or rhythm or genre - they were just sitting there waiting for me.

Through mountain dawn and gentle breeze

By starstream lit and breaking heart

O'er highland pass and tossing seas

To seek again by craft or art

A love long caught and scattered fine

In dust and spume and foam of grieve-ing heartbreak, in the sands of time...

Left here to weep and sink amid

Tsunami billows, lost, a-fear'd

Where love's once gleaming joy was hid.

Alas it's left me, lone and drear

With heart and self adriften'd, dear'd

Oh come my love, my only dear

In scattered winds, my once-loved whole

My heart, my self, my only soul.

The same was so of a later verse about a close friend's loss of his dear wife of many years, much wept-over, arriving with me between sleep and waking - a liminal space, for me the centre of linguistic creativity. Here was no rhyme (mostly - I was not conscious of what there was till much later) but with rhythm and cadence already in place when I looked to write it down the next day.

Dear friend, you have been given a great gift. The gift of steadfastness to see her die

love to hold her through the night

and close her eyes.

sorrow to see her gone

courage to travel the hard death road with her 
and then without her

impossible courage - to return

return to those who called you,

braveness to live alone,

fortitude to find your friends

and Friends, again,

grief and pain and more-more pain

living a lone soul's earthly life,

light of the ocean

beloved wife

star of the sea, for aye.

(quoted by permission of the dedicatee) [1]

The newly discovered blocks of language came, and still come to me, in prose form too; perhaps 'poetic prose is a better description and arrived, without exception in dreams. That is where my creative, created, literature comes from. I do not know the name, the place the time. But I know it is somehow from beyond myself, outside even of earthly mortal creation. But without our human creativity, our very own action, our very selves it could never have come to be.

This must seem - as it does, indeed, to myself - unbelievable the product of religious or mystical ideologies, paranormal, hallucinatory; certainly not the scientific hard evidence expected of linguistic analysis. And yet - it is indeed language-in-use, something perhaps more commonly occurring than we realise and certainly recognised by the ancients, not to be denied just because it has seldom been fully described or taken seriously.

So: my dreams and their outcomes - or rather my 'Dreams', or what I have come to refer to as 'power dreams' have become a very personal and eventually linguistic experience for me. It is also something new to me, now in my 80 s. Perhaps it is a 'delusion' in some way? But if so it is a sustained delusion, a kind of myth of symbolic worth, true, I believe, to itself. Remember too that anthropologists, and linguists too, have long held a reputation for giving credence, pro tem at least, to the beliefs and language practices they find, and listen to them tenderly. And after all - there is the linguistic result, not to be denied, a thing in the real world of language and of publication.

For it was not just isolated poems but stories and then, eventually, a novel, Black Inked Pearl. A complete narrative followed on from my dreams as I visited, unplanned, a dream world. Transformed into words they carried, no question, that familiar narrative- experience of human living, the form in which we shape our lives and being - a form in which, perhaps not fortuitously, I already had an interest.The stories were somehow 'told' to me, unexpected, unsought, in a series of dreams, later viewed, differently, as a series of quasi-visions revealed between sleeping and waking. They existed already - as do, miraculously, the events and practices of the field, situation for field-researchers: waiting there for me, for us. They were there before I knew it: independent of my thoughts or actions, enlarging as I struggled, as in the field, to note and record them and as my observations grew, uncovering themselves before my watching senses. [2]

The narrative came as visually, or perhaps better described as emotionally communicated scenes fully there, I knew it, but only gradually unveiling themselves to me as I walked further in that strange land. Not at that stage dynamic, as is the way of language, they were static tableaus rather than dreams in the usual - narrativised - sense. Things fell gradually into place as, chapter by chapter, their detail was revealed to me. Eventuating finally in fully realised form, written then, by me, forgotten, as my first novel, Black inked pearl.

Can that it be that here is some original form of language, denied in our waking hours but recovered and recoverable in song and dream? Listen to the beautiful declaimed words of lovely poetry, think of Shakespeare's or Elizabeth Barrett Browning's love poems: can they be seen to originate in the trial-and-error, pencil and rubber, endeavours of earthly concerns? Or the sonnet form itself? Petrarch hardly constructed it from nothing - so where did he find it? Can not dreams and imagination be seen, whatever the proximate causes, as the ultimate generating force of human language?

I wonder too whether in this series of experiences I was in some way in touch with and drawing from some deep sphere beyond myself: Jung's collective unconscious, the world's store of myth and fairytale, 'heaven', or the kind of shared mind depicted in John Wyndham's fictional Midwich Cuckoos, the special knowledge by which devoted dogs know of their owners' return (Sheldrake 2000), or, in more overtly scientific mode, the 'one mind' hypothesised by Larry Dossey (2013) and similar forward looking scientists. Now that even social scientists no loner shun concepts like 'imagination', 'inspiration', even perhaps 'the divine', it may once again be allowable to reacall Homer's notion of magically 'winged words', and connect language and its origin and continuing creation to ideas of mystery, trance, entrancement, of shared minds and past-present-memory, and to the heightened awareness that is at last becoming a subject of study" the experience that we so richly we find in music, in meditation, in prayer - and also, often 'lost' in a book or 'not with it', in the beauties of literature, both spoken and written.

Once again, like so many theories of the first origin, and nature, of language, each creation was a single event in my case, a series of single unique events. Again, it is monogenesis. For here we find, here and now, the unique, single-experienced origin of language, the specific enacted events in which in practice, we now see, it exists for each and every one of us in voice and word and text.

Gpoing back to that first human band and the common language it spoke, that deep pool to which perhaps, in liminal apace we still have some kind of access. But what about the emergence, then, of separate, different, languages? That too is a question, a related one. 
This looks different. Here polygenesis is surely not only the conventional but also the correct answer. We can indeed envisage language initially being single, the resource of small bands in communication among themselves. But as they diverged and travelled, so must language(s) - another lesson we have learnt is that there is nothing 'fixed' or, so to speak intrinsic about a language. Here the biblical story of the Tower of Babel has much to be said for it, albeit to be understood in mythic metaphorical terms. Here is one, retold, version:

Once upon a time all the creatures of the earth understood one another. They may have had their own ways, it is true. But they understood. But then one day, we do not understand when or wherefore, they gathered all together in some great building that they themselves had, arrogantly, constructed, and there in the pride and foolishness of their hearts, they climbed it. And those on each branch, the great branched Tree of Language, found themselves speaking each a new tongue.

And the great understanding between creatures was gone as if it had never been.

Or again, in the Bible version:

Now the whole world had one language and a common speech. As people moved eastward they found a plain in Shinar and settled there.

They said to each other, "Come, let's make bricks and bake them thoroughly", They used brick instead of stone, and tar for mortar. Then they said, "Come, let us build ourselves a city, with a tower that reaches to the heavens, so that we may make a name for ourselves; otherwise we will be scattered over the face of the whole earth."

But the Lord came down to see the city and the tower the people were building. The Lord said, "If as one people speaking the same language they have begun to do this, then nothing they plan to do will be impossible for them. Come, let us go down and confuse their language so they will not understand each other."

So the Lord scattered them from there over all the earth, and they stopped building the city. That is why it was called Babel-because there the Lord confused the language of the whole world.

For many centuries, millennia indeed of human history that was the situation. It was of people scatteredover the face of the whole earth speaking together in small clumps but on a wider scale: mutual linguistic un-understanding. This indeed is how we experience language(s) today, a sphere in which continuities and separate development must surely hold sway. We can think the ancient but (sub specie aeternitatis) relatively recent history of language(s) discerned in the findings if comparable philology: the great tree of languages gradually diverging - French and Spanish and Portuguese from Latin; Brazilian Portuguese (though not as yet very far) from the continental version; the many forms of English now gradually emerging; and the great historical Indo-European family of languages of which Sanskrit is as fully a member as Portuguese or English. That is the situation as we know it today - linguistic disparity and continuity.

But then, the mythic tale continues - and perhaps mythic as it is we have something to learn from it On the fiftieth day of a great festival in the first century $A D$ a great multitude of people gathered together from every nation, speaking many different languages. Here is the story as told in the biblical book of Acts.

When the day of Pentecost came, they were all together in one place. Suddenly a sound like the blowing of a violent wind came from heaven and filled the whole house where they were sitting. They saw what seemed to be tongues of fire that separated and came to rest on each of them. All of them were filled with the Holy Spirit and began to speak in other tongues as the Spirit enabled them.

Now there were staying in Jerusalem God-fearing Jews from every nation under heaven. When they heard this sound, a crowd came together in bewilderment, because each one heard their own language being spoken. Utterly amazed, they asked: "Aren't all these who are speaking Galileans? Then how is it that each of us hears them in our native language? Parthians, Medes and Elamites; residents of Mesopotamia, Judea and Cappadocia, Pontus and Asia, Phrygia and Pamphylia, Egypt and the parts of Libya near Cyrene; visitors from Rome (both Jews and converts to Judaism); Cretans and Arabs-we hear them declaring the wonders of God in our own tongues!" Amazed and perplexed, they asked one another, "What does this mean?" (The Bible, Acts, Chapter 2).

A miracle indeed!

It is worth noting that the occurrence was at once taken as something mystical and extraordinary, at any rate out of the ordinary run of things. At the time, we are told, some people attributed it to alcohol ('they are drunk', they said). But we too know of the phenomena of hypnosis, of druginduced trance, anaesthesia, of 'speaking with tongues', of being 'beside oneself' or in a situation when ordinary verbal language seems to have become irrelevant. There are instances too of people recovering form a deep period of unconsciousness and, remarkably, finding themselves speaking, and fluently too, some language of which they had never had, could not have had, any experience. Is there, somehow, somewhere, some pool of language(s) through which, as in pre-Babel times, all we humans share the same deep resource? Some kind of Jungian 'collective unconscious' perhaps, or the 'togetherness of prayer' in which many believe, or the idea of 'noosphere' put forward by philosopher-scientists like Teilhardt de Chardin? Or indeed -a point to return to - 'one mind', shared and common to the many? Given the remarkable nature of the Pentecost story, and indeed of language, voice and text altogether, are these not-so-uncommon notions under one name or another perhaps not equally believable?

So far this account of the origin of language has focused on the oral, the unwritten. So too, unsurprisingly, 
have the theories of the origin of language itself with which we began. For language after all was surely both logically and chronologically prior to writing. But given the importance and spread of written language today, and on a world-wide scale, let me conclude by some brief observations on the origins of writing and, more particularly, of scripts.

Scripts - yes, the plural. For here we are surely with polygenesis not a single origin. This is not just because of of their huge and diverse number - phonographic (both alphabetic and syllabic), pictographic, semasiographic - but their uses in many many diverse languages. There is also the plain fact that in many cases we know their origins and purposes and makers. They began, they are recorded, at discrete moments of history.

Here too, as with language, it is hard to see these scripts as arising in any but a full, systematic, form. Fictional accounts may speculate, fancifully, as for example in Rudyard Kipling's engaging Just so stories, about their being constructed letter by separate letter. But all the scripts we know are systematic interrelated wholes. Only $n$ this way can they function.

Furthermore it is recounted not just in myth and memory but in documented written accounts that such scripts were invented - or should we say discovered? - by a single person, working on his or her (usually his) own. So often the origin is seen as divine, made by a saint, a seer, a heaven-inspired king or leader. Often too, as in Africa (home, despite its misleading reputation, to a plethora of scripts), the script it is recounted to the originator in a dream and seen as coming direct from heaven or enshrining 'the Word of God'. So too in some cases is its outcome: think of the tablets (tablets filled with writing) brought direct from heaven by Moses in the Christian Bible, or the divinely spoken Koran, the direct sounded and resounding words of Allah himself. Here is yet another brick in our growing intimation of the somehow divine origin of language and its arts.

Multiple documented origins indeed, we seem inescapably with polygenesis. But sometimes I wonder. Given the notorious conservatism of scripts and of letters that we can, indeed, often trance over the centuries, might some ultimate shared origin lie behind the present-day variety? An origin not perhaps of distinct letters, but of principles? That too is something to ponder. Perhaps we are again back with a monogenesis, a single, divine(?) origin.

So dear friends, keep talking, thinking, writing and, as in the epics of Homer, let your winged words that come from the divine realms of heaven and the gift of language fly the world and the skies in the breath, the life, the great mystery of humankind.

\section{References}

Ariel, M. (2010) Defining Pragmatics, Cambridge University Press.
Carter, R. (2004) Language and Creativity, London: Routledge.

Darwin, C. (1871) The Descent of Man and Selection in Relation to Sex, 2 vols. London: Murray.

Chomsky, N. (2007) The Architecture of Language, Oxford University Press. by Noam Chomsky

De Chardin, T. (1999) Writings (Modern Spiritual Masters Series), Orbis.

Dossey, L. (2013) One Mind: How Our Individual Mind Is Part of a Greater Consciousness and Why It Matters, Hay House.

Duranti, A. (1997) Linguistic Anthropology, Cambridge: Cambridge University Press

Finnegan, R. (2014) Communicating; The Multiple Modes of Human Communication, London: Routledge.

Finnegan, R. (2015a) Where is Language? London; Bloomsbury.

Finnegan, R. (2015b) Black Inked Pearl. A Girl's Quest, New York: Garn Press.

Finnegan, R. (2016) Kate's Black Ink Poems, Old Bletchley: Callender Press.

Harris, R. (ed.) (1996) The Origin of Language. Bristol: Thoemmes Continuum).

Jousse, M. (1925) 'Le style oral rythmique et mnémotechnique chez les verbo-moteurs', Revue Archives d Philosophie 2, 4.

Jung, C. G. (1991) The Archetypes and the Collective Unconscious (Collected Works of C. G. Jung), London: Routledge.

Kendon, A. (2004) Gesture.Visible Action as Utterance, Cambridge: Cambridge University Press.

MacNeill, D. (2005) Gesture and Thought, Chicago: University of Chicago Press.

Müller, M. (1861) 'The theoretical stage, and the origin of language', Lecture 9 from Lectures on the Science of Language, reprinted in Harris 1996.

Paget, R. (1930) Human speech: some observations, experiments, and conclusions as to the nature, origin, purpose and possible improvement of human speech. London: Routledge \& Kegan Paul.

Pinker, S. (2009). Language Learnability and Language Development, Cambridge MA: Harvard University Press.

Sapir, E. (1921) Language, New York: Harcourt Brace.

Sheldrake, R. (2000) Dogs That Know When Their Owners Are Coming Home: And Other Unexplained Powers of Animals, Arrow.

Swann, J. et al. (eds) (2011) Creativity in Language and Literature: The State of the Art, Palgrave-Macmillan.

Verschueren, J. et al. (eds) (1995) Handbook of Pragmatics. Amsterdam: Benjamins.

Wyndham, J. (1964) The Midwich Cuckoos, Harmondsworth: Penguin. 